(c) American Dairy Science Association, 2004.

\title{
A Comparison of Processed Conventional Corn Silage to Unprocessed and Processed Brown Midrib Corn Silage on Intake, Digestion, and Milk Production by Dairy Cows*
}

\author{
T. L. Ebling and L. Kung, Jr. \\ Delaware Agricultural Experimental Station Department of Animal and Food Sciences \\ College of Agriculture and Natural Resources, University of Delaware, Newark 19716-2150
}

\begin{abstract}
We studied the effects of mechanical processing and type of hybrid on the nutritive value of corn silage for lactating cows. Treatments were brown midrib (BMR) corn silage that was unprocessed (U-BMR), BMR corn silage that was processed (P-BMR), and a conventional corn silage that was processed (P-7511). All silages were harvested at a theoretical chop length of $19 \mathrm{~mm}$. The chemical compositions of the silages were similar among treatments except that BMR silages were lower in lignin and higher in protein than P-7511. Brown midrib silages had greater $30-\mathrm{h}$ in situ and in vitro NDF digestion than did P-7511, and processing had no effect on 30-h in situ and in vitro fiber digestion, but it increased in situ starch digestion after 3 and $12 \mathrm{~h}$ of incubation. Both processed silages had a smaller proportion of particles $>1.91 \mathrm{~cm}$ and fewer whole corn kernels compared with unprocessed silage. Lactating cows were fed a total mixed ration (TMR) consisting of $42 \%$ of each silage type, $40 \%$ concentrate, $10 \%$ alfalfa silage, and $8 \%$ alfalfa hay (DM basis). Cows fed TMR containing P-BMR ate more DM and produced more milk than cows fed P-7511. At feeding, the TMR containing U-BMR had a larger proportion of particles $>1.91 \mathrm{~cm}$ when compared with the TMR of cows fed processed silages, and after $24 \mathrm{~h}$ the difference was even greater, indicating that cows fed unprocessed corn silage sorted more. Cows fed TMR with P-7511 and P-BMR had greater total tract digestibility of organic matter, crude protein, and starch compared with cows fed U-BMR. In vivo digestibility of neutral detergent fiber was greatest for cows fed P-BMR when compared with the other treatments.
\end{abstract}

(Key words: mechanical processing, brown midrib, corn silage)

Received November 11, 2003.

Accepted March 29, 2004.

Corresponding author: L. Kung, Jr.; e-mail: LKSilage@udel.edu.

*Partially supported by Mycogen Seeds, Indianapolis, IN.
Abbreviation key: BMR = brown midrib, P-7511 = processed 7511 corn silage, $\mathbf{P}$-BMR = processed BMR corn silage, U-BMR = unprocessed BMR corn silage.

\section{INTRODUCTION}

Selection of corn hybrids with high nutritive values and mechanical processing of the whole corn plant are 2 methods that have been extensively studied in recent years to improve the utilization of corn silage. Specifically, brown midrib (BMR) hybrids have a lower concentration of lignin throughout the plant because of a reduction in the activity of the enzyme $O$-methyltransferase (Barriere and Argillier, 1993). Lower concentrations of lignin in corn silage have resulted in improved fiber digestion (Lechtenberg et al., 1972; Oba and Allen, 1999, 2000) and, in several instances, increased animal performance (Eastridge, 1999). Mechanical processing increases the nutritive value of the corn plant by exposing the starch in the corn kernel to rumen bacteria for digestion (Johnson et al., 2003) and improves packing density of silage (Johnson et al., 2002). Processed silage offers the potential for better nutrient utilization by the lactating cows and can increase animal performance (Bal et al., 2000b; Andrae et al., 2001).

We know of only one other published study evaluating the nutritive value of processed BMR silage (P-BMR) (Schwab et al., 2002) and could find no comparisons between processed conventional corn silage and PBMR. Thus, we evaluated the effectiveness of mechanical processing on the composition and nutritive value of BMR corn silage for lactating cows. We also compared P-BMR and unprocessed BMR corn silage (U-BMR) to a conventional corn silage hybrid that was processed. Evaluations were made via in situ and in vitro methods for digestibility and by feeding the silages to lactating cows and comparing their effects on intake, digestion, and production.

\section{MATERIALS AND METHODS}

\section{Corn Silage}

Two varieties of corn silage were used in this study: $7511 \mathrm{FQ}$ (Mycogen Seeds, Indianapolis, IN), a medium- 
tall, forage quality hybrid (115 d relative maturity), and 867 (Mycogen Seeds), a BMR variety (118 d relative maturity). Corn was planted at the University of Delaware Dairy in fields of silt loam soil at a theoretical planting density of 72,500 seeds/ha $(29,000$ seeds/A) in $0.76 \mathrm{~m}$ (30 in.) rows. The site had been managed as corn-alfalfa rotation every $4 \mathrm{yr}$ for at least $12 \mathrm{yr}$. In the last year of each alfalfa rotation, alfalfa was harvested in the spring then followed by no-till planting of corn using Round-Up (Monsanto Co., St. Louis, MO) or Gramoxone (Syngenta Crop Protection, Inc., Greensboro, NC). Small grain planting (typically barley or wheat) followed in the fall of each year. Management strategies included application of sheep, beef, and horse manure, and tandem disk harrow-cultivation followed by a field finisher applied with rolling basket and tines. Dry fertilizer starter (10-20-20, N- $\mathrm{P}_{2} \mathrm{O}_{5}-\mathrm{K}_{2} \mathrm{O}$; Milford Fertilizer, Milford, DE) was applied at a rate of $112 \mathrm{~kg} /$ ha, as was Broad Strike-Dual herbicide (Dow Elanco, Indianapolis, IN) and a 30\% urea ammonium nitrate solution (UAN; CF Industries, Inc., Long Grove, IL). Plants were harvested at about $35 \% \mathrm{DM}$ and one-half milk line with a New Holland FP230 (New Holland, PA) pull-type harvester equipped with a mechanical processor. Treatments at harvest were U-BMR, P-BMR, and processed 7511FQ (P-7511). The roller clearance was set at $2 \mathrm{~mm}$, and the theoretical length cut was set at $19 \mathrm{~mm}$ for processed silages. The deflector screen, which diverts the forage to the rollers, was removed, and the theoretical length cut was unchanged for the unprocessed corn silage. Approximately 50 tonnes of each treatment were ensiled in farm-scale bag silos (Ag/ Bag International, Ltd., Warrenton, OR) and stored for 7 mo before feed out.

\section{Diets and Cows}

Twenty-four multiparous and 6 primiparous Holstein cows averaging $143 \pm 32$ DIM (average milk production of about $43 \mathrm{~kg} / \mathrm{d}$ ) were housed in a free stall barn with Calan gates (American Calan, Northwood, NH). During a 14-d pretreatment period, cows were fed a TMR at $105 \%$ of their expected intake for ad libitum consumption once daily at $0800 \mathrm{~h}$. The TMR contained (DM basis) 14\% P-7511, 14\% P-BMR, 14\% U-BMR, 10\% alfalfa silage, $8 \%$ chopped alfalfa hay, and $40 \%$ of a pelleted concentrate (Table 1). The amount of feed offered and refused was measured daily for each cow. At the end of the pretreatment period, cows were blocked by milk yield, DIM, and parity and randomly allocated to 1 of the 3 treatment TMR containing P-7511, P-BMR, or U-BMR. The TMR (Table 2) contained $42 \%$ (DM basis) of the respective corn silage, $10 \%$ alfalfa silage, $8 \%$ chopped alfalfa hay, and $40 \%$ pelleted concentrate.
Table 1. Composition (\% DM) of the concentrate fed to lactating cows.

\begin{tabular}{|c|c|}
\hline Ingredient & $\%$ \\
\hline Corn meal fine & 20.4 \\
\hline Soybean meal, $47.5 \% \mathrm{CP}$ & 17.6 \\
\hline Distillers dried grains & 12.3 \\
\hline Gluten feed & 12.3 \\
\hline Soybean hulls & 7.13 \\
\hline Soybean roasted & 5.78 \\
\hline Corn gluten, $60 \% \mathrm{CP}$ & 5.02 \\
\hline Wheat middlings & 3.97 \\
\hline Fat blend $^{1}$ & 3.06 \\
\hline Soybean meal, extruded & 2.81 \\
\hline Limestone, $(37 \% \mathrm{Ca})$ & 2.54 \\
\hline Molasses blend ${ }^{2}$ & 2.04 \\
\hline Sesquicarbonate & 2.05 \\
\hline Salt & 1.06 \\
\hline Protein blend ${ }^{3}$ & 0.66 \\
\hline Dicalcium phosphate ${ }^{4}$ & 0.50 \\
\hline Urea & 0.41 \\
\hline Magnesium oxide & 0.21 \\
\hline Selenium, $(0.06 \% \mathrm{Se})$ & 0.11 \\
\hline Trace minerals ${ }^{5}$ & 0.04 \\
\hline Vitamins $^{6}$ & 0.04 \\
\hline
\end{tabular}

${ }^{1}$ Feed grade combination of tallow, poultry, and porcine fats

${ }^{2}$ Contained (DM basis) $0.5 \% \mathrm{Ca}, 0.03 \mathrm{~g}$ of $\mathrm{Cu} / \mathrm{kg}, 5.0 \%$ crude fat, $3.0 \% \mathrm{CP}, 0.50 \mathrm{~g}$ of I/kg, $0.40 \% \mathrm{Mg}, 1.49 \mathrm{mcal} / \mathrm{kg} \mathrm{NEL}, 45.5 \%$ nonstructural carbohydrates, $3.2 \% \mathrm{~K}, 0.70 \% \mathrm{~S}, 63 \% \mathrm{TDN}, 0.50 \% \mathrm{P}, 0.01 \mathrm{~g}$ of $\mathrm{Zn} / \mathrm{kg}$.

${ }^{3}$ Dried blood meal, hydrolyzed poultry feathers, fishmeal, calcium carbonate, and ethoxyquin.

${ }^{4}$ Contained (DM basis) $27 \% \mathrm{Ca}$ and $20 \% \mathrm{P}$.

${ }^{5} 2.1 \% \mathrm{Ca}, 1.6 \mathrm{~g}$ of $\mathrm{Co} / \mathrm{kg}, 40 \mathrm{~g}$ of $\mathrm{Cu} / \mathrm{kg}, 4.0 \mathrm{~g}$ of $\mathrm{I} / \mathrm{kg}, 6.0 \mathrm{~g}$ of $\mathrm{Fe} /$ $\mathrm{kg}, 150 \mathrm{~g}$ of $\mathrm{Mn} / \mathrm{kg}, 13.0 \% \mathrm{~S}$, and $160 \mathrm{~g}$ of $\mathrm{Zn} / \mathrm{kg}$.

${ }^{6}$ Contained (DM basis) $26,400 \mathrm{kIU}$ of vitamin A/kg, $8800 \mathrm{kIU} / \mathrm{kg}$ of vitamin D, and 165,000 IU of vitamin $\mathrm{E} / \mathrm{kg}$.

Cows were fed their respective diets for a 6 -wk treatment period. All cows had been treated with recombinant bST (Posilac bST, Monsanto Co.) every 2 wk starting 4 wk before and throughout the study. Fresh water was available at all times, and the care of animals was via accepted protocols for animal research (Anonymous, 1989).

Cows were milked twice daily at 0700 and $1900 \mathrm{~h}$, and production was recorded at each milking. In addition, milk was sampled proportionately to yield once weekly from consecutive p.m. and a.m. milkings and analyzed for percentage of fat, protein, and lactose by infrared analysis (method 972.160; AOAC, 2000) (MidEast Milk Laboratory Services, Inc., Hagerstown, MD).

Milk composition was calculated by adding together the compositions after being weighted for the proportion of milk produced at each milking. Cows were weighed on 2 consecutive $d$ at the start and the end of the treatment period.

\section{Feed Analyses}

Samples of the corn silages, alfalfa haylage, and TMR were sampled 3 times weekly and composited prior to 
Table 2. Chemical and physical composition of the TMR fed to lactating dairy cows. ${ }^{1}$

\begin{tabular}{|c|c|c|c|}
\hline Item & P- $7511^{2}$ & P-BMR ${ }^{3}$ & $\mathrm{U}-\mathrm{BMR}^{4}$ \\
\hline $\mathrm{DM}, \%$ & 51.9 & $\begin{array}{c}49.8 \\
(\% \text { of } \mathrm{DM})\end{array}$ & 49.6 \\
\hline $\mathrm{NEL},{ }^{5} \mathrm{Mcal} / \mathrm{kg}$ & 1.61 & 1.61 & 1.61 \\
\hline $\mathrm{CP}, \%$ & 16.3 & 17.1 & 17.3 \\
\hline $\mathrm{ADF}, \%$ & 23.0 & 21.0 & 21.8 \\
\hline NDF, $\%$ & 33.9 & 33.5 & 33.8 \\
\hline Starch, \% & 20.9 & 20.2 & 19.0 \\
\hline $\mathrm{Ca}, \%$ & 0.86 & 0.84 & 0.87 \\
\hline $\mathrm{P}, \%$ & 0.35 & 0.36 & 0.37 \\
\hline $\mathrm{Mg}, \%$ & 0.24 & 0.26 & 0.27 \\
\hline $\mathrm{K}, \%$ & 1.38 & 1.57 & 1.70 \\
\hline $\mathrm{S}, \%$ & 0.22 & 0.24 & 0.21 \\
\hline $\mathrm{Fe}, \mathrm{ppm}$ & 207 & 246 & 254 \\
\hline $\mathrm{Mn}, \mathrm{ppm}$ & 58 & 52 & 52 \\
\hline $\mathrm{Zn}, \mathrm{ppm}$ & 50 & 52 & 53 \\
\hline $\mathrm{Cu}, \mathrm{ppm}$ & 21 & 22 & 21 \\
\hline \multicolumn{4}{|c|}{ Particle size distribution ${ }^{6}$} \\
\hline$>1.91 \mathrm{~cm}$ & 6 & 6 & 11 \\
\hline 0.79 to $1.91 \mathrm{~cm}$ & 40 & 39 & 41 \\
\hline$<0.79 \mathrm{~cm}$ & 54 & 55 & 48 \\
\hline
\end{tabular}

\footnotetext{
${ }^{1}$ Average analyses of 6 weekly samples. Minerals were analyzed on a single composite sample from 6 wk.

${ }^{2}$ TMR included processed conventional corn silage (7511FQ; Mycogen Seeds, Indianapolis, IN).

${ }^{3}$ TMR included processed brown midrib (BMR) corn silage.

${ }^{4}$ TMR included unprocessed BMR corn silage.

${ }^{5} \mathrm{NRC}(2001)$.

${ }^{6}$ Feed particle size distribution of the fresh TMR prior to feeding using a Penn State forage particle separator.
}

weekly analyses. The chopped hay and pelleted concentrate were sampled once weekly for analyses. Composited samples from each week were dried in a $60^{\circ} \mathrm{C}$ forced-air oven for $48 \mathrm{~h}$ for the determination of DM. The dried feed samples were ground through a 1-mm screen using a Cyclone Sample Mill (UDY Corp., Fort Collins, CO). Samples were analyzed for laboratory DM by placing $0.5 \mathrm{~g}$ into a $100^{\circ} \mathrm{C}$ oven for $24 \mathrm{~h}$. Samples were also analyzed for NDF by using sulfite and amylase (Van Soest et al., 1991), ADF (Robertson and Van Soest, 1981) using an Ankom ${ }^{200}$ Fiber Analyzer (Ankom Technology, Fairport, NY), and acid detergent lignin following $\mathrm{ADF}$ analysis using $72 \% \mathrm{H}_{2} \mathrm{SO}_{4}$. Crude protein was calculated by multiplying total $\mathrm{N}$ by 6.25 after total combustion (Leco CNS 2000 Analyzer, St. Joseph, MI). Ash content was determined by placing $0.5 \mathrm{~g}$ of sample into a $600^{\circ} \mathrm{C}$ furnace for $4 \mathrm{~h}$. Starch concentration was analyzed by the procedure described by Hall (2000).

Silages were also analyzed for fermentation end products. Twenty-five grams of the weekly silage composite samples were homogenized for $1 \mathrm{~min}$ in $225 \mathrm{~mL}$ of sterile quarter-strength Ringer solution (Oxoid BR52; Unipath, Basingstoke, UK). The $\mathrm{pH}$ of the water extract was determined. A portion of the water extract was filtered through Whatman 54 filter paper (Whatman, Clifton, $\mathrm{NJ}$ ), acidified with $50 \% \mathrm{H}_{2} \mathrm{SO}_{4}$, and frozen prior to further analysis. Water extracts were analyzed for ammonia $\mathrm{N}$ by using the phenol-hypochlorite procedure described by Weatherburn (1967). A portion of the extracts was also acidified with $25 \%$ m-phosphoric acid (5:1, vol/vol) and analyzed for VFA by gas chromatography using a Hewlett Packard 5890 gas chromatograph (Hewlett Packard, Avondale, PA) with a $530 \mu \mathrm{m}$ Carbowax $20 \mathrm{M}$ column and flame ionization detector. The chromatograph oven was programmed as follows: $70^{\circ} \mathrm{C}$ for $1 \mathrm{~min}, 5^{\circ} \mathrm{C}$ increase/min until $100^{\circ} \mathrm{C}$ was reached, then $45^{\circ} \mathrm{C}$ increase/min to $170^{\circ} \mathrm{C}$, and maintained a final holding time of $5 \mathrm{~min}$. The water extracts were also analyzed for D- and L-lactic acids using an enzymatic kit (kit 826-UV; Sigma Aldrich, St. Louis, MO). For analysis of D-lactic acid, L-lactic dehydrogenase was replaced with a similar amount of D-lactic dehydrogenase (Sigma L-9636). L-lactic acid (Sigma L-2250) and D-lactic acid (Sigma L-1000) were used as standards for their respective assays. Lactic acid was reported as the sum of L- and D-lactic acid.

Fresh weekly composite samples ( $250 \mathrm{~g})$ of each corn silage and their respective TMR were subjected to particle size analysis (Lammers et al., 1996) using the Pennsylvania State Separator box (Nasco, Fort Atkins, WI). The proportion of sample collected on each section and the number of whole kernels were determined. Weekly composite corn silage samples were also analyzed for in vitro and in situ digestibility. A 30-h in vitro NDF digestibility was determined by weighing $0.25 \mathrm{~g}$ of sample into F57 bags (acetone washed) placed in a Daisy ${ }^{\mathrm{II}}$ Incubator (Ankom Technology) following the general procedure of Goering and Van Soest (1970). Dry matter, $\mathrm{NDF}$, and starch digestibility were determined by a macro in situ method (Joanne Siciliano-Jones, personal communication, 2002), which was conducted at the FARME Institute, Inc. (Homer, NY). Samples were prepared by simulating the chewing action of the cow via manual crushing. Approximately $5 \mathrm{~g}$ (DM basis) of sample were weighed (triplicate for each treatment) into rumen in situ filter bags (Ankom Technology) that measured $10 \times 20 \mathrm{~cm}$ with a pore size of $50 \mu$. Bags were heat-sealed and placed into small, mesh laundry bags before inserting the bags into a cannulated lactating Holstein cow. The bags were removed after 3,12 , and $30 \mathrm{~h}$ of incubation. The donor cow was fed $20.5 \mathrm{~kg} / \mathrm{d}$ (DM basis) of a diet formulated to meet NRC (2001) requirements. The ration was comprised of $28.3 \%$ corn silage, $14.9 \%$ alfalfa silage, $3.8 \%$ alfalfa hay, and $53.0 \%$ concentrate. Starch and fiber were analyzed as previously described. 


\section{Digestion Trial}

The 8 highest yielding lactating cows from each treatment group were used to measure in vivo apparent digestibility during wk 5 of the treatment period. Fecal samples were collected every $8 \mathrm{~h}$ to obtain 12 samples per cow and were placed into a freezer $\left(-20^{\circ} \mathrm{C}\right)$ for later analyses. Three hundred grams of wet feces from each collection point were mixed to form a single composite sample of feces for each cow. Two hundred fifty grams of each fecal composite were screened for kernel content. Fecal $\mathrm{pH}$ was determined by mixing $10 \mathrm{~g}$ of sample into $100 \mathrm{~mL}$ of deionized $\mathrm{H}_{2} \mathrm{O}$. Dry matter was determined by placing $300 \mathrm{~g}$ of sample into an aluminum pan in a $60^{\circ} \mathrm{C}$ forced-air oven for $72 \mathrm{~h}$. Dried samples were ground through a 1-mm screen using a Cyclone Sample Mill (UDY Corp.) and analyzed for laboratory DM, $\mathrm{NDF}, \mathrm{ADF}, \mathrm{CP}$, starch, and ash (as described previously). Indigestible NDF was determined on the NDF residue after $120 \mathrm{~h}$ of in vitro fermentation in the Daisy ${ }^{\mathrm{II}}$ Incubator and was used as a marker for total tract digestibility (Oba and Allen, 1999). Indigestible NDF for each TMR and each component of the TMR was determined using samples collected during the period of fecal collection.

\section{Evaluation of TMR Sorting}

On the second to last day of the trial, all cows were fed $120 \%$ of their expected intake to provide TMR samples throughout a 24-h collection period to monitor sorting. Upon the completion of feeding at $0700 \mathrm{~h}, 1 \mathrm{~kg}$ of the TMR was sampled every $6 \mathrm{~h}(0,6,12,18$, and $24 \mathrm{~h})$ for each cow. The weight of the remaining feed was recorded and placed back into the bunk. The proportion of particles on each section of the Pennsylvania State Separator box (Nasco) was determined as previously described.

\section{Statistical Analysis}

Chemical data are presented on a DM basis. Digestibility data from the in vivo digestion trial was analyzed as a completely randomized design. Data from the last $7 \mathrm{~d}$ of the pretreatment period from the lactation trial were used in a covariate analysis. Production data from the lactation trial were analyzed as a completely randomized design with weekly observations as repeated measurements using the analysis of variances procedure by the General Linear Models procedure of SAS (SAS Inst., Inc., Cary, NC). Differences among means were tested using Tukey's Test (Snedecor and Cochran, 1980). An $\alpha$ level of $P<0.05$ was deemed significant.
Table 3. Nutrient composition (\% DM) and particle size of corn silages fed to lactating cows. ${ }^{1}$

\begin{tabular}{|c|c|c|c|}
\hline Item & $\mathrm{P}-7511^{2}$ & P-BMR ${ }^{3}$ & $\mathrm{U}^{-\mathrm{BMR}^{4}}$ \\
\hline DM, \% & 37.7 & 33.7 & 33.5 \\
\hline $\mathrm{CP}, \%$ & 6.19 & 8.37 & 8.21 \\
\hline $\mathrm{ADF}, \%$ & 24.0 & 24.5 & 24.0 \\
\hline $\mathrm{NDF}, \%$ & 41.6 & 41.8 & 41.0 \\
\hline Lignin, \% & 2.25 & 1.02 & 0.87 \\
\hline Starch, \% & 31.7 & 28.4 & 27.4 \\
\hline $\mathrm{pH}$ & 3.51 & 3.63 & 3.59 \\
\hline Lactic acid, \% & 3.04 & 3.56 & 3.69 \\
\hline Acetic acid, \% & 1.24 & 1.48 & 1.53 \\
\hline Propionic acid, \% & 0.36 & 0.08 & 0.36 \\
\hline \multicolumn{4}{|l|}{ Particle size distribution ${ }^{5}$} \\
\hline$>1.91 \mathrm{~cm}$ & 3 & 8 & 14 \\
\hline 0.79 to $1.91 \mathrm{~cm}$ & 56 & 60 & 63 \\
\hline$<0.79 \mathrm{~cm}$ & 41 & 32 & 23 \\
\hline Whole kernels ${ }^{6}$ & 9 & 7 & 39 \\
\hline
\end{tabular}

${ }^{1}$ Average analyses of 6 weekly composite samples.

${ }^{2}$ Processed conventional corn silage (7511FQ; Mycogen Seeds, Indianapolis, IN).

${ }^{3}$ Processed brown midrib (BMR) corn silage.

${ }^{4}$ Unprocessed BMR corn silage.

${ }^{5}$ Feed particle size distribution of the fresh TMR prior to feeding using a Penn State forage particle separator.

${ }^{6}$ Per $250 \mathrm{~g}$ of wet forage.

\section{RESULTS}

\section{Silage Composition}

The nutrient composition and size of forage particles for the 3 corn silages is presented in Table 3. On average, BMR corn silages had a DM content of $33.6 \%$, whereas P-7511 was slightly drier, with a DM content of $37.7 \%$. The CP concentration was similar for the BMR corn silages (average of $8.29 \%$, DM basis) but was lower for P-7511 (6.19\%). No differences were found in the $\mathrm{NDF}$ (average of $41.5 \%$ ) and ADF (average of 24.2\%) concentrations of the 3 corn silages. As expected, PBMR (1.02\%) and U-BMR (0.87\%) had lower concentrations of lignin when compared with P-7511 (2.25\%). The concentration of starch was $27.4 \%$ in U-BMR, $28.4 \%$ in P-BMR, and $31.7 \%$ in P-7511. The P-7511 had the lowest $\mathrm{pH}$ (3.51) and the lowest concentration of lactic $(3.04 \%)$ and acetic acid (1.24\%) when compared with the other 2 silages. A larger proportion of particles $>1.91$ $\mathrm{cm}$ was present in the U-BMR (14\%) when compared with P-BMR (8\%) and P-7511 (3\%). A larger proportion of particles also remained on the middle screen $(0.79$ to $1.91 \mathrm{~cm})$ for U-BMR (63\%) than for P-BMR (60\%) and P-7511 (56\%). Thus, a smaller proportion of particles $(<0.79 \mathrm{~cm})$ remained on the bottom screen for U-BMR (23\%) than for P-BMR (32\%) and P-7511 (41\%). A greater number of whole, intact kernels remained in U-BMR $(n=39)$ than in the processed silages $(n=7$ to 9$)$. 
Table 4. In vitro and in situ digestion (\%, DM basis) of a processed conventional corn silage hybrid (7511FQ; Mycogen Seeds, Indianapolis, IN; P-7511; P-7511), a processed brown midrib hybrid (P-BMR), or an unprocessed brown midrib hybrid (U-BMR).

\begin{tabular}{lcccc}
\hline & & \multicolumn{3}{c}{ Corn silage } \\
\cline { 3 - 5 } Item & $\begin{array}{l}\text { Time of } \\
\text { incubation (h) }\end{array}$ & P-7511 & P-BMR & U-BMR \\
\hline In vitro digestion $^{1}$ & & & & \\
NDF & 30 & $39.9^{\mathrm{b}}$ & $54.0^{\mathrm{a}}$ & $51.0^{\mathrm{a}}$ \\
In situ digestion $^{2}$ & & & & \\
DM & 3 & $46.1^{\mathrm{a}}$ & $46.3^{\mathrm{a}}$ & $41.3^{\mathrm{b}}$ \\
& 12 & $52.1^{\mathrm{a}}$ & $52.7^{\mathrm{a}}$ & $47.2^{\mathrm{b}}$ \\
Starch & 30 & $62.6^{\mathrm{b}}$ & $66.9^{\mathrm{a}}$ & $66.6^{\mathrm{a}}$ \\
& 3 & $73.9^{\mathrm{cd}}$ & $77.9^{\mathrm{c}}$ & $69.9^{\mathrm{d}}$ \\
NDF & 12 & $85.7^{\mathrm{a}}$ & $89.4^{\mathrm{a}}$ & $74.2^{\mathrm{b}}$ \\
& 30 & 97.4 & 97.2 & 90.7 \\
& 3 & 0 & 0 & 0 \\
\hline
\end{tabular}

${ }^{\mathrm{a}, \mathrm{b}}$ Means with unlike superscripts differ $(P<0.05)$.

${ }^{\mathrm{c}, \mathrm{d}}$ Means with unlike superscripts differ $(P<0.06)$.

${ }^{1} \mathrm{NDF}$ digestibility after $30 \mathrm{~h}$ of in vitro fermentation.

${ }^{2}$ Using a macro in situ digestion technique.

\section{In Vitro and In Situ Digestion}

Digestibility of NDF after $30 \mathrm{~h}$ of in vitro digestion (Table 4) was markedly higher for P-BMR (51.0\%) and U-BMR (54.0\%) when compared with P-7511 (39.9\%). Digestibility of nutrients was also measured by a macro in situ technique. Dry matter digestibility at $3 \mathrm{~h}$ was lower for the unprocessed silage (41.3\%) compared with the processed silages (average of $46.2 \%$ ). By $12 \mathrm{~h}$, the digestibility of the unprocessed silage (47.2\%) remained lower than the processed silages (average of 52.4\%). However, by $30 \mathrm{~h}$, the DM digestibility of both BMR silages was greater (average of $66.8 \%$ ) by 4 percentage units than the P-7511 (62.6\%). Processing BMR corn silage tended to improve $(P<0.06)$ starch digestion when compared with U-BMR after $3 \mathrm{~h}$ of incubation. After $12 \mathrm{~h}$ of incubation, both processed silages had more starch digestion than U-BMR, but these differences where not found after $30 \mathrm{~h}$ of incubation. No differences were found in NDF digestibility at 3 or 12 $\mathrm{h}$ among the silages. However, after $30 \mathrm{~h}$ of digestion, NDF digestion was greater in both BMR silages when compared with P-7511 (35.5\% and $31.9 \%$ vs. $22.7 \%$, respectively).

\section{Lactation and Digestion}

Milk production, milk composition, and DMI of cows fed TMR containing P-7511, P-BMR, or U-BMR are presented in Table 5. Dry matter intake was greatest for cows fed a TMR that contained P-BMR $(25.9 \mathrm{~kg} / \mathrm{d})$ when compared with those fed P-7511 $(23.4 \mathrm{~kg} / \mathrm{d})$. Cows fed the former also tended $(P<0.12)$ to eat more DM
Table 5. Performance of dairy cows fed a processed conventional corn silage hybrid (7511FQ; Mycogen Seeds, Indianapolis, IN; P7511), a processed brown midrib hybrid (P-BMR), or an unprocessed brown midrib hybrid (U-BMR).

\begin{tabular}{lcccl}
\hline Item & P-7511 & P-BMR & U-BMR & SE \\
\hline DMI, kg/d & $23.4^{\mathrm{b}}$ & $25.9^{\mathrm{a}}$ & $24.5^{\mathrm{ab}}$ & 0.6 \\
Milk, kg/d & $41.4^{\mathrm{b}}$ & $44.3^{\mathrm{a}}$ & $42.5^{\mathrm{ab}}$ & 0.8 \\
$\begin{array}{l}\text { Milk fat } \\
\text { \% }\end{array}$ & 3.16 & 2.94 & 3.17 & 0.13 \\
$\mathrm{~kg} / \mathrm{d}$ & 1.29 & 1.32 & 1.34 & 0.04 \\
Milk protein & & & & \\
$\%$ & 2.79 & 2.76 & 2.75 & 0.03 \\
kg/d & 1.15 & 1.22 & 1.17 & 0.03 \\
3.5\% FCM, kg/d & $38.8^{\mathrm{d}}$ & $40.8^{\mathrm{c}}$ & $40.0^{\mathrm{cd}}$ & 0.8 \\
FCM/DMI, kg/d & 1.78 & 1.74 & 1.75 & 0.04 \\
\hline
\end{tabular}

${ }^{\mathrm{a}, \mathrm{b}}$ Means with unlike superscripts differ $(P<0.05)$.

${ }^{\mathrm{c}, \mathrm{d}}$ Means with unlike superscripts differ $(P<0.08)$.

than those fed U-BMR. Dry matter intake was not different between cows fed U-BMR and P-7511. Milk yield was also greater from cows fed P-BMR $(44.3 \mathrm{~kg} / \mathrm{d})$ when compared with cows fed P-7511 (41.4 kg/d), and it was also numerically greater than from cows fed U-BMR. Milk fat and protein did not differ among treatments. Yield of $3.5 \%$ FCM yield tended to be greater $(P<0.08)$ for cows fed a TMR with P-BMR compared with P-7511.

Fecal characteristics and apparent nutrient digestion from the total tract is presented in Table 6. Fecal $\mathrm{pH}$ was lowest for cows fed U-BMR, and these cows also had the largest amount of whole kernels excreted in the feces. Cows fed diets with processed silages (P-7511 and P-BMR), on average, had a greater OM (65.1\% vs. $56.5 \%)$, CP (65.0\% vs. $58.2 \%)$, and starch (98.9\% vs. 88.5\%) digestibility compared with cows fed U-BMR. However, cows fed P-BMR had a greater ADF (39.6\%) and NDF (42.1\%) digestibility than cows fed either P7511 (32.8 and $34.1 \%$, respectively) or U-BMR (32.1 and $30.0 \%$, respectively) in a TMR.

Table 6. Fecal characteristics and apparent in vivo total tract digestibility from cows fed a processed conventional corn silage hybrid (7511FQ; Mycogen Seeds, Indianapolis, IN; P-7511), a processed brown midrib hybrid (P-BMR), or an unprocessed brown midrib hybrid (U-BMR).

\begin{tabular}{lllll}
\hline Item & P-7511 & P-BMR & U-BMR & SE \\
\hline Fecal pH & $6.92^{\mathrm{a}}$ & $6.97^{\mathrm{a}}$ & $6.81^{\mathrm{b}}$ & 0.15 \\
$\begin{array}{l}\text { Whole kernels/250 g of } \\
\text { wet feces }\end{array}$ & $4^{\mathrm{b}}$ & $3^{\mathrm{b}}$ & $20^{\mathrm{a}}$ & 3 \\
& & \multicolumn{4}{c}{$(\% \mathrm{DM})$} & \\
\cline { 2 - 5 } OM & $64.2^{\mathrm{a}}$ & $66.0^{\mathrm{a}}$ & $56.5^{\mathrm{b}}$ & 1.1 \\
$\mathrm{DM}$ & $61.7^{\mathrm{a}}$ & $63.8^{\mathrm{a}}$ & $54.0^{\mathrm{b}}$ & 1.1 \\
$\mathrm{CP}$ & $64.2^{\mathrm{a}}$ & $65.7^{\mathrm{a}}$ & $58.2^{\mathrm{b}}$ & 1.4 \\
ADF & $32.8^{\mathrm{b}}$ & $39.6^{\mathrm{a}}$ & $32.1^{\mathrm{b}}$ & 2.4 \\
NDF & $34.1^{\mathrm{b}}$ & $42.1^{\mathrm{a}}$ & $30.0^{\mathrm{b}}$ & 1.9 \\
Starch & $99.0^{\mathrm{a}}$ & $98.7^{\mathrm{a}}$ & $88.5^{\mathrm{b}}$ & 0.7 \\
\hline
\end{tabular}

${ }^{\mathrm{a}, \mathrm{b}}$ Means in rows with unlike superscripts differ $(P<0.05)$. 
Table 7. The effect of mechanical processing and corn hybrid on particle size distribution (\%) of TMR fed to dairy cows.

\begin{tabular}{lccc}
\hline Item & P-7511 & P-BMR & U-BMR \\
\hline At feeding & & & \\
$>1.91 \mathrm{~cm}$ & $6.4^{\mathrm{b}}$ & $6.9^{\mathrm{b}}$ & $9.6^{\mathrm{a}}$ \\
0.79 to $1.91 \mathrm{~cm}$ & $34.3^{\mathrm{b}}$ & $39.9^{\mathrm{a}}$ & $39.4^{\mathrm{a}}$ \\
$<0.79 \mathrm{~cm}$ & $58.7^{\mathrm{a}}$ & $52.6^{\mathrm{b}}$ & $50.4^{\mathrm{b}}$ \\
$6 \mathrm{~h}$ after feeding & & & \\
$>1.91 \mathrm{~cm}$ & $6.7^{\mathrm{b}}$ & $7.4^{\mathrm{b}}$ & $11.4^{\mathrm{a}}$ \\
0.79 to $1.91 \mathrm{~cm}$ & $34.4^{\mathrm{b}}$ & $35.3^{\mathrm{ab}}$ & $36.7^{\mathrm{a}}$ \\
$<0.79 \mathrm{~cm}$ & $58.9^{\mathrm{a}}$ & $57.3^{\mathrm{a}}$ & $51.9^{\mathrm{b}}$ \\
$12 \mathrm{~h}$ after feeding & & & \\
$>1.91 \mathrm{~cm}$ & $10.9^{\mathrm{b}}$ & $9.4^{\mathrm{b}}$ & $13.8^{\mathrm{a}}$ \\
0.79 to $1.91 \mathrm{~cm}$ & $34.6^{\mathrm{b}}$ & $36.9^{\mathrm{ab}}$ & $37.7^{\mathrm{a}}$ \\
$<0.79 \mathrm{~cm}$ & $54.5^{\mathrm{a}}$ & $53.7^{\mathrm{a}}$ & $48.5^{\mathrm{b}}$ \\
$18 \mathrm{~h}$ after feeding & & & \\
$>1.91 \mathrm{~cm}$ & $10.3^{\mathrm{b}}$ & $11.3^{\mathrm{b}}$ & $12.8^{\mathrm{a}}$ \\
0.79 to $1.91 \mathrm{~cm}$ & $34.9^{\mathrm{b}}$ & $37.8^{\mathrm{ab}}$ & $38.9^{\mathrm{a}}$ \\
$<0.79 \mathrm{~cm}$ & $54.8^{\mathrm{a}}$ & $50.9^{\mathrm{b}}$ & $48.3^{\mathrm{b}}$ \\
$24 \mathrm{~h}$ after feeding & & & \\
$>1.91 \mathrm{~cm}$ & $9.9^{\mathrm{b}}$ & $11.3^{\mathrm{b}}$ & $19.4^{\mathrm{a}}$ \\
0.79 to $1.91 \mathrm{~cm}$ & $36.2^{\mathrm{b}}$ & $38.2^{\mathrm{a}}$ & $37.9^{\mathrm{ab}}$ \\
$<0.79 \mathrm{~cm}$ & $53.9^{\mathrm{a}}$ & $50.5^{\mathrm{b}}$ & $42.7^{\mathrm{c}}$ \\
\hline
\end{tabular}

a,b,c Means with unlike superscripts differ $(P<0.05)$.

${ }^{1}$ Processed conventional corn silage (7511FQ; Mycogen Seeds, Indianapolis, IN).

${ }^{2}$ Processed brown midrib (BMR) corn silage.

${ }^{3}$ Unprocessed BMR corn silage.

At initial feeding, cows offered a TMR containing UBMR had a greater proportion of feed particles that were $>1.91 \mathrm{~cm}$ compared with cows fed P-BMR and P7511 (Table 7). Cows fed the BMR TMR had more and less particles on the 0.79 - to $1.91-\mathrm{cm}$ screen and $<0.79$ cm bottom pan than cows fed P-7511, respectively. In general, similar trends were observed through $18 \mathrm{~h}$ of feeding. After $24 \mathrm{~h}$, the proportion of particles $>1.91 \mathrm{~cm}$ was still greatest for cows fed U-BMR (19.4\%) compared with cows fed P-BMR (9.9\%) and those fed P-7511 (11.3\%) silage.

\section{DISCUSSION}

In the present study, the theoretical chop length of forages was $19 \mathrm{~mm}$ because previous work from our laboratory has shown that amount of forage retained on the screen that represents particles $>1.91 \mathrm{~cm}$ decreases by 10 to 15 percentage units after freshly chopped corn forage has gone through a silo bagging machine (J. Neylon and L. Kung, unpublished data, University of Delaware, 2002). Some caution should also be taken when comparing the effects of processing of corn silage, as studies have not been consistent in adjusting for theoretical chop length. In the current study, all silages were harvested at the same theoretical chop length. However, in general, the effects of processing BMR corn silage were similar to those found with conventional hybrids (Shinners et al., 2000; Andrae et al., 2001; Johnson et al., 2002). For example, processing decreased the number of whole, intact corn kernels in silage (from 39 to $<10$ per $250 \mathrm{~g}$ of silage) and decreased the proportion of particles $>1.91 \mathrm{~cm}$ from $14 \%$ in U-BMR to 8 and $3 \%$ in P-BMR and P-7511, respectively. The P-7511 hybrid had a smaller proportion of particles $>1.91 \mathrm{~cm}$ and a larger proportion of particles $<0.79 \mathrm{~cm}$ than did either P-BMR or U-BMR, possibly because of the slightly higher DM content (37.7\%) than in the BMR silages (average of 33.6\%). Because processing crushed or cracked the majority of corn kernels in corn silage, there were fewer whole corn kernels in the manure of cows fed processed silages compared with that found in cows fed U-BMR. Cows fed processed silages also had a higher fecal $\mathrm{pH}$ than cows fed U-BMR, most likely because there was more starch digestion in the rumen than in the hindgut. Similar to the results of Bal et al. (2000a), we found that in the macro in situ incubations, where whole, wet forages were used, processed corn silages (P-BMR and P-7511) had similar and more rapid disappearance of starch after 3 and $12 \mathrm{~h}$ of incubation than did U-BMR. Cows fed diets with P-BMR and P-7511 also had higher total tract digestion of starch than those cows fed U-BMR. Similar findings have been reported by Schwab et al. (2002) specifically with BMR corn silage and by others with conventional corn silage hybrids (Dhiman et al., 2000; Weiss and Wyatt, 2000). Improvements in in situ and in vivo starch digestion supported the fact that processing increased the availability of starch in the corn kernel to microbial attachment and digestive enzymes.

The effect of processing on the digestion of fiber in corn silage has been variable. Johnson et al. (2003) and Schwab et al. (2002) reported decreases in fiber digestion from processing, but Rojas-Bourrilon et al. (1987) reported that processing increased the digestion of fiber from whole plant corn. In our study, processing had no effect on the extent of fiber digestion in BMR corn silage measured in vitro or via a macro in situ technique, which supports previous research by Bal et al. (2000a) and Doggett et al. (1998). In contrast to the in vitro and in situ results, apparent in vivo total tract digestion of fiber in our study was greater in cows fed PBMR when compared with those fed U-BMR. However, total tract digestion of fiber from cows fed U-BMR was not different from that of cows fed P-7511, which might indicate that fiber digestion was depressed in cows fed U-BMR, possibly because of a lack of energy in the rumen attributable to the abundance of intact kernels in the diet. This finding is in contrast to data reported by Schwab et al. (2002) and Dhiman et al. (2000), who observed a reduction in total tract NDF digestion when 
cows were fed diets containing processed vs. unprocessed corn silages.

In a review of the literature, Eastridge (1999) reported that, on average, BMR corn silages contained $34 \%$ less lignin and had an in situ or in vitro NDF digestibility that was $19 \%$ higher when compared with non-BMR hybrids. In this study, there was a greater difference in the concentration of lignin (55\% less) between BMR corn silages and P-7511, which resulted in a proportional higher increase $(38 \%)$ in in vitro NDF digestion. In agreement with the data summarized by Eastridge (1999), we generally found no differences between other nutrient components of the silages with the exception of a higher concentration of $\mathrm{CP}$ in the $\mathrm{P}$ BMR, but our conventional hybrid was not the isogenic hybrid of BMR.

Pretrial estimates of the CP content of P-7511 were higher than what was sampled during the actual lactation study. Thus, cows fed P-7511 had a TMR with a slightly lower protein content than cows fed the BMR silages, but protein intake was in excess of NRC requirements and should not have been a limiting factor. In general, cows produced milk with a moderate to low fat test, probably because of the high concentration of corn silage in the diets and because effective fiber might have been limiting. The proportion of particles from the TMR that were $>1.91 \mathrm{~cm}$ ranged from 6 to $11 \%$, which is slightly lower than recommended levels (Lammers et al., 1996). Processing BMR silage tended to increase DMI $(+1.4 \mathrm{~kg} / \mathrm{d} ; P<0.12)$ and milk production $(+1.8$ $\mathrm{kg} / \mathrm{d} ; P<0.13)$ when compared with cows fed U-BMR. In the only other comparison that we know of where BMR corn silage was subjected to processing, Schwab et al. (2002) reported no effect on intake or milk production from processing. In past studies, processing has had variable effects on milk production (Satter et al., 1999), because variables such as stage of corn maturity, cow productivity, and percentage of corn silage in the diet can affect production responses to treatment. When compared with cows fed P-7511, those animals fed PBMR consumed 2.5 more $\mathrm{kg}$ of $\mathrm{DM} / \mathrm{d}$ and produced 2.9 more $\mathrm{kg}$ of milk/d. In a summary of 9 lactation studies, Eastridge (1999) reported that cows fed BMR corn silage, on average, produced $0.95 \mathrm{~kg}$ more milk/d than cows fed a non-BMR silage, but positive effects were not seen in all studies. Although numerically greater, cows fed U-BMR did not eat more DM or produce more milk than those fed P-7511.

The proportion of TMR particles $>1.91 \mathrm{~cm}$ was not different between cows fed diets with processed silages throughout the 24-h feeding period. However, the TMR containing unprocessed silage had a consistently larger proportion of particles in this category than did either TMR containing processed silages at all sampling points. After $24 \mathrm{~h}$ in the feed bunk, this difference was greatest, suggesting that more sorting occurred between 18 and $24 \mathrm{~h}$ of feeding. Extensive sorting of feed particles in TMR has been reported by Kononoff et al. (2003), Leonardi and Armentano (2003), and Martin (1999), and the data from the current study suggests that mechanical processing of corn silage may decrease this problem, especially for cows fed only once daily.

\section{CONCLUSION}

Mechanical processing of whole-plant BMR corn silage resulted in smaller forage particles but a decreased number of whole, intact kernels in silage and in the manure of cows. Processing had no effect on in vitro or in situ fiber digestion, but it improved early in situ digestion and in vivo digestion of starch. Cows fed PBMR ate more and produced more milk than did those fed the processed conventional corn silage. Cows fed processed BMR corn silage also tended to eat and produced more milk with a similar composition than did cows fed U-BMR. These data show that feeding cows P-BMR results in enhanced production over cows fed processed conventional corn silage. Including processed corn silage (regardless of hybrid type) into the TMR fed to cows once daily resulted in less sorting between 18 and $24 \mathrm{~h}$ of access to feed.

\section{ACKNOWLEDGMENTS}

The authors thank Karl Nestor (Mycogen Seeds, Indianapolis, IN) for support throughout this study. We also thank Richard Morris, Tony Timko, Scott Hopkins, Jeanne Neylon, Daryl Kleinschmit, and Jill Ladd for animal care and analytical assistance.

\section{REFERENCES}

Andrae, J. G., C. W. Hunt, G. T. Pritchard, L. R. Kennington, J. H. Harrison, W. Kezar, and W. Mahanna. 2001. Effect of hybrid, maturity, and mechanical processing of corn silage on intake and digestibility by beef cattle. J. Anim. Sci. 79:2268-2275.

Anonymous. 1989. Handbook for Agricultural Animal Care and Use in Research and Teaching. Agricultural Animal Care and Use Committee, Univ. of Delaware, Coll. of Agric. Natural Res., Newark, DE.

Association of Official Analytical Chemists, International. 2000. Official Methods of Analysis. 17th ed. AOAC, Arlington, VA.

Bal, M. A., R. D. Shaver, A. G. Jirovec, K. J. Shinners, and J. G. Coors. 2000b. Crop processing and chop length of corn silage: Effects on intake, digestion, and milk production by dairy cows. J. Dairy Sci. 83:1264-1273.

Bal, M. A., R. D. Shaver, K. J. Shinners, J. G. Coors, J. G. Lauer, R. J. Straub, and R. G. Koegel. 2000a. Stage of maturity, processing, and hybrid effects on ruminal in situ disappearance of wholeplant corn silage. Anim. Feed Sci. Technol. 86:83-94.

Barriere, Y., and O. Argillier. 1993. Brown midrib genes of maize: A review. Agronomie 13:865-876.

Dhiman, T. R., M. A. Bal, Z. Wu, V. R. Moreira, R. D. Shaver, L. D. Satter, K. J. Shinners, and R. P. Walgenbach. 2000. Influence of 
mechanical processing on utilization of corn silage by lactating dairy cows. J. Dairy Sci. 83:2521-2528.

Doggett, C. G., C. W. Hunt, J. G. Andrae, G. T. Prichard, W. Kezar, and J. H. Harrison. 1998. Effect of hybrid and processing on digestive characteristics of corn silage. J. Anim. Sci. 76(Suppl. 1):196. (Abstr.)

Eastridge, M. L. 1999. Brown midrib corn silage. Pages 179-190 in Proc. Tri-State Dairy Nutrition Conf. Ohio State University, Columbus, $\mathrm{OH}$.

Goering, H. K., and P. J. Van Soest. 1970. Forage fiber analysis (apparatus, reagents, procedures, and some applications). Agric. Handbook No. 3790, ARS-USDA, Washington, DC.

Hall, M. B. 2000. Neutral Detergent Soluble Carbohydrates Nutritional Relevance and Analysis: A Laboratory Manual. Univ. Florida Ext. Serv., Gainesville, Fl.

Johnson, L. M., J. H. Harrison, D. Davidson, C. Hunt, W. C. Mahanna, and K. Shinners. 2003. Corn silage management: Effects of hybrid, maturity, chop length, and mechanical processing on rate and extent of digestion. J. Dairy Sci. 86:3271-3299.

Johnson, L. M., J. H. Harrison, D. Davidson, W. C. Mahanna, K. Shinners, and D. Linder. 2002. Corn silage management: Effects of maturity, inoculation, and mechanical processing on pack density and aerobic stability. J. Dairy Sci. 85:434-444.

Kononoff, P. J., A. J. Heinrichs, and H. A. Lehman. 2003. The effect of corn silage particle size on eating behavior, chewing activities, and rumen fermentation in lactating dairy cows. J. Dairy Sci. 86:3343-3353.

Lammers, B. P., D. R. Buckmaster, and A. J. Heinrichs. 1996. A simple method for the analysis of particle sizes of forage and total mixed rations. J. Dairy Sci. 79:922-928.

Lechtenberg, V. L., L. D. Muller, L. F. Bauman, C. L. Rhykerd, and R. F. Barnes. 1972. Laboratory and in vitro evaluation in $F_{2}$ populations of brown midrib mutants of Zea mays. L. Agron. J. 64:657-660.

Leonardi, C., and L. E. Armentano. 2003. Effect of quantity, quality, and length of alfalfa hay on selective consumption by dairy cows. J. Dairy Sci. 86:557-564.

Martin, R. 1999. TMR particle distribution analysis at six hour time intervals. Pages 7-16 in Proc. Univ. Wisconsin Arlington Dairy Day. Dairy Sci. Dep., Univ. Wisconsin, Madison.
National Research Council. 2001. Nutrient Requirements of Dairy Cattle. 7th rev. ed. Nat. Acad. Sci., Washington, DC.

Oba, M., and M. S. Allen. 1999. Effects of brown midrib 3 mutation in corn silage on dry matter intake and productivity of high yielding dairy cows. J. Dairy Sci. 82:135-142.

Oba, M., and M. S. Allen. 2000. Effects of brown midrib 3 mutation in corn silage on productivity of dairy cows fed two concentrations of dietary neutral detergent fiber: 3. Digestibility and microbial efficiency. J. Dairy Sci. 83:1350-1358.

Robertson, J. B., and P. J. Van Soest. 1981. The detergent system of analysis and its application to human foods. Page 123 in The Analysis of Dietary Fiber in Food. W. P. T. James and O. Theander, ed. Marcel Dekker, New York, NY.

Rojas-Bourrillon, A., J. R. Russel, A. Trenkle, and A. D. McGilliard. 1987. Effects of rolling on the composition and utilization by growing steers of whole-plant corn silage. J. Anim. Sci. 64:303311.

Satter, L. D., Z. Wu, V. R. Moreira, and M. A. Bal, and R. D. Shaver. 1999. Processing corn silage. Pages 49-58 in Proc. 24th Annu. Minnesota Forage Conf. American Forage and Grassland Council, Rochester, MN.

Schwab, E. C., R. D. Shaver, K. J. Shinners, J. G. Lauer, and J. G. Coors. 2002. Processing and chop length effects in brown-midrib corn silage on intake, digestion, and milk production by dairy cows. J. Dairy Sci. 85:613-623.

Shinners, K. J., A. G. Jirovec, R. D. Shaver, and M. Bal. 2000. Processing whole-plant corn silage with crop processing rolls on a pull-type forage harvester. Appl. Eng. Agric. 16:323-331.

Snedecor, G. W., and W. G. Cochran. 1980. Statistical Methods. 6th ed. Iowa State Univ. Press, Ames.

Van Soest, P. J., J. B. Robertson, and B. A. Lewis. 1991. Methods for dietary fiber, neutral detergent fiber, and non-starch polysaccharides in relation to animal nutrition. J. Dairy Sci. 74:35833597.

Weatherburn, M. W. 1967. Phenol-hypochlorite reaction for determination of ammonia. Anal. Chem. 39:971-974.

Weiss, W. P., and D. J. Wyatt. 2000. Effect of oil content and kernel processing of corn silage on digestibility and milk production by dairy cows. J. Dairy Sci. 83:351-358. 